\title{
EVALUATION OF THE CONTENT OF HEAVY METALS IN FLUVISOLS OF FLOODPLAIN AREA DEPENDING ON THE TYPE OF LAND USE
}

\author{
Mirosław Kobierski ${ }^{1}$ \\ 1 Department of Soil Science and Soil Protection, University of Technology and Life Sciences in Bydgoszcz, \\ Bernardyńska 6/8, 85-029 Bydgoszcz, Poland, e-mail: kobierski@utp.edu.pl
}

Received: 2014.09.12

Accepted: 2014.10 .27

Published: 2015.01.02

\begin{abstract}
The aim of the research was the evaluation of the potential contamination with heavy metals in Fluvisols, used as grasslands and arable soils of Vistula River floodplain in the area of the Chełmiński and Nadwiślański Complex of Landscape Parks. The indicators proposed by Håkanson allow to evaluate the potential ecological risk of the contamination with heavy metals associated with the accumulation of one metal or a combination of multiple metals. The mean total content of $\mathrm{Cd}, \mathrm{Pb}, \mathrm{Ni} \mathrm{Cu}, \mathrm{Zn}, \mathrm{Mn}$, as well as Fe in Fluvisols at the depth of 120-150 cm was assumed as the content of the local geochemical background and it was: $1.0 \mathrm{mg} \cdot \mathrm{kg}^{-1}, 22.8 \mathrm{mg} \cdot \mathrm{kg}^{-1}, 26.9 \mathrm{mg} \cdot \mathrm{kg}^{-1}$, $1.4 \mathrm{mg} \cdot \mathrm{kg}^{-1}, 60.8 \mathrm{mg} \cdot \mathrm{kg}^{-1}, 591 \mathrm{mg} \cdot \mathrm{kg}^{-1}$, and $17.6 \mathrm{~g} \cdot \mathrm{kg}^{-1}$, respectively. The values of the indicators such as contamination factor $(\mathrm{CF})$, enrichment factor (EF) revealed higher levels of the accumulation of heavy metals in the soils of grasslands, which shows that the method of their use has a significant effect on the total metal content. Contamination with heavy metals in the surface layer of the investigated Fluvisols was found, and in terms of the content with cadmium a moderate and considerable potential ecological risk was reported. Due to the fact that no unfavourable effect of trace elements on the riverside environment was proved and that the floodplain areas are under agricultural use, to evaluate the contamination with metals, the limit values for the soils of agricultural land were assumed as stipulated in the Regulation of Minister of the Environment of September 9, 2002. According to that criterion, the soils studied do not qualify as contaminated with metals. Only in one of the soil sampling points the total content of zinc was higher than the one determined as the maximum for agricultural land soils, namely $350 \mathrm{mg} \cdot \mathrm{kg}^{-1}$. A significantly positive correlation was noted between the content of $\mathrm{C}$ org and the total content of metals as well as very numerous interactions between metals. The results of cluster analysis confirm that the method of use determines the concentration of metals in the surface layer of the Fluvisols studied.
\end{abstract}

Keywords: heavy metals, floodplain, potential ecological risk index, enrichment factor

\section{INTRODUCTION}

The areas within the Chełmiński and Nadwiślański Complex of Landscape Parks undergo annual flood events. Every year the Vistula River is affected by flooding owing to the number of tributaries and shallow riverbeds that involve overflowing during spring floods or seldom periods of heavy rain in summer. The natural floodplain is limited with the floodbank and it makes up wasteland grown with riparian woodlands and it remains under agricultural use as grasslands and arable land. In many places the right bank of the Vistula River is regularly eroded and the amount of the deposited sediments on the floodplain depends on the reach of the flood as well as local landscape-related conditions. The sedimentation and erosion processes observed in the river channel take a form of a loss of fine sediments at the foot of the riverbanks during strong currents, especially spring floods. More coarse sediments, namely gravels and sand are transported by the river and deposited within the riverbed. However, during flood recessions, the fine sediment (silt 
and clay fraction) that is transported along the river is accumulated on the floodplain [Kordowski 2003]. The fluvial deposits, rich in humic and mineral colloids, act as a collector of water pollution in the river catchment, and as such they can constitute an essential source of chemical substances [Wyżga, Ciszewski 2010, Skorbiłowicz, Samborska 2014]. It is difficult to define unambiguously how soil properties change during overflowing in the periods of flooding as well as to what extent they affect the content of metals [Macklin, Klimek 1992, Singh et al. 2005]. An increased total content of metals in Fluvisols of floodplains comes mostly from the properties of sedimentation material but also from agricultural use [Kobierski, Piotrowska 2010]. Anthropogenic heavy metals deposited into soils as a result of human activities are more mobile than lithogenic and pedogenic metals the origins of which are difficult to distinguish [Kabata-Pendias 2004]. The accumulation of metals in soils increases with the decreasing particle size but the main factors controlling the behaviour of trace metals are organic matter contents, iron and manganese hydroxides, pH and redox potential [Harmsen 2007, Van Gestel 2008]. Physical and chemical properties of Fluvisols can reflect the processes which occur in riverside environment as well as give a possibility of interpreting the changes which occur in the entire catchment since they are a resultant of geological, pedogenic and anthropogenic factors [Saint-Laurent et al. 2010].

The aim of the study was to characterize the Fluvisols of the floodplain of the Grudziądz Basin on the evaluation of the total content of $\mathrm{Cd}, \mathrm{Pb}$, $\mathrm{Ni} \mathrm{Cu}, \mathrm{Zn}, \mathrm{Mn}$, and Fe depending on the type of land use.

\section{MATERIALS AND METHOD}

The research covered the floodplain areas between the Vistula riverbed and the flood embankment within the Grudziądz Basin (the Lower Vistula River). The riverside environment was evaluated in 12 study areas (zones). The samples from Fluvisol profiles numbered I.19, I.24, I.26, I.28, I.30, I.32 were taken from grasslands, while samples II.20, II.21, II.23, II.25, II.29, II.31 - from arable land. For the purpose of this study, soil samples were taken from layers: $0-30 \mathrm{~cm}, 60-90 \mathrm{~cm}, 120$ $150 \mathrm{~cm}$, in which the basic properties as well as the total content of $\mathrm{Cd}, \mathrm{Pb}, \mathrm{Ni}, \mathrm{Cu}, \mathrm{Mn}$ and $\mathrm{Fe}$ were determined. The soil analyses were performed according to the commonly applied methods:

- texture, using the areometric method [PNISO-11277: 2005],

- $\mathrm{pH}$ in $1 \mathrm{~mol} \cdot \mathrm{dm}^{-3} \mathrm{KCl}$ solution (1:2,5 soil-solution ratio), using the potentiometric method [ISO 10390: 2005].

The content of total organic carbon was assayed with analyser vario Max CN Elementar Analysensysteme GmbH (Hanau, Germany). The total content of metals was assayed after the mineralization in the mixture of acids $\mathrm{HF}$ and $\mathrm{HClO}_{4}$ [Crock, Severson 1980]. The precision of this procedure was confirmed with reference materials TILL-3 for metals determination. The concentration of metals was defined using atomic absorption spectrometry (AAS, Philips 9100, Cambridge, UK). Soil properties were treated with standard statistics and statistical tests (ANOVA and the Tukey test). Pearson's correlation analysis was also done between the soil properties and total content of metals variables. The statistical analyses were made using Statistica 7.0 (StatSoft Inc, Tulsa, USA).

\section{Potential ecological risk index}

The potential ecological risk index $R I$ is used to assess the ecological risk associated with the accumulation of one metal or a combination of multiple metals in surface soils or sediments, which was proposed by [Håkanson 1980]. The value of $R I$ can be calculated with the following formulas:

$$
\begin{gathered}
C_{f}^{i}=C^{i} / C_{b}^{i} \\
C_{d e g}=\Sigma C_{f}^{i}{ }_{f} \\
E_{r}^{i}=T \times C_{f}^{i} \\
R I=\Sigma E_{r}^{i}
\end{gathered}
$$

where: $C_{f}^{i}$ - the contamination factor;

$C^{i}$-the content of metal in topsoil;

$C_{b}^{i}$ - the background concentration of metal;

$C_{d e g}$ - contamination degree;

$E_{r}^{i}{ }_{r}$ - the potential risk of a single metal;

$T^{r}$ - the toxic-response factor for a given heavy metal;

$R I$ - the sum of potential risk of asingle metal caused by the overall contamination.

In order to unify the assessment results, the local background contents of heavy metals were used as the reference values for calculating the indices. As the content of the geochemical back- 
ground for respective elements their mean total content in the 120-150 cm layer was assumed. The sum of the value of $C_{f}^{i}$ for respective metals is expressed by the degree of contamination $\left(C_{d e g}\right)$ of the ecosystem (Table 1).

Table 1. Contamination factor $C_{f}^{i}$ and degree of contamination categories $C_{d e g}$

\begin{tabular}{|c|l|c|}
\hline$C_{f}^{i}$ classes & $C_{f}^{i}$ and $C_{d e g}$ terminologies & $C_{d e g}$ classes \\
\hline$C_{f}^{i}<1$ & Low contamination $C_{f}^{i}$ and $C_{d e g}$ & $C_{d e g}<8$ \\
\hline $1 \leq C_{f}^{i}<3$ & Moderate $C_{f}^{i}$ and $C_{d e g}$ & $8 \leq C_{d e g}<16$ \\
\hline $3 \leq C_{f}^{i}<6$ & Considerable $C_{f}^{i}$ and $C_{d e g}$ & $16 \leq C_{d e g}<32$ \\
\hline$C_{f}^{i} \geq 6$ & Very high $C_{f}^{i}$ and $C_{d e g}$ & $C_{d e g} \geq 32$ \\
\hline
\end{tabular}

Based on the Håkanson [1980] approach, the toxic-response factors for $\mathrm{Zn}$ is $1 ; \mathrm{Cu}-2 ; \mathrm{Pb}, \mathrm{Cu}$, $\mathrm{Ni}-5 ; \mathrm{Cd}-30$. Potential ecological risk index $(R I)$ is a methodology developed by Håkanson, who proposed five categories of $E_{r}^{i}$, and four categories of $R I$.

The following terminologies was used to describe the risk factor: $E_{r}^{i}<40$, low potential ecological risk; $40 \leq E^{i}<80$, moderate potential ecological risk; $80 E^{i}<160$, considerable potential ecological risk; $160 \leq E_{r}^{i}<320$, high potential ecological risk; and $E_{r}^{i} \geq 320$, very high ecological risk. The potential ecological risk index $(R I)$ was defined as the sum of the risk factors: $R I<150$, low ecological risk; $150 \leq R I<300$, moderate ecological risk; $300 \leq R I<600$, considerable ecological risk; and $R I>600$, very high ecological risk.

\section{Enrichment factor}

A common approach to estimating the human activity impact on soils is to calculate a normalized enrichment factor $(E F)$ for metal concentrations above background levels. The values of the enrichment factor $(E F)$ were calculated according to the formula:

$$
E F=\left[C_{n} / C_{n F e}\right] /\left[B_{n} / B_{n F e}\right]
$$

where: $C_{n}$ - total content of metal;

$C_{n F e}$-total content of $\mathrm{Fe}$ as the reference element;

$B_{n}-$ content of metal for the geochemical background;

$B_{n F e}$ - content of Fe in geochemical background [Martin, Meybeck 1979].

Such elements as Ti, Al, Li, $\mathrm{Zr}$ as well as $\mathrm{Fe}$ get slightly anthropogenically accumulated and they do not participate actively in geochemical cycles. Neither do they have substantial anthropogenic sources. Based on $E F$ value the enrichment categories were determined: $<2-$ deficiently to minimal enrichment, 2-5 moderate enrichment, 5-20 - considerable enrichment, 20-40 very high enrichment, $>40$ extremely high enrichment [Sutherland et al. 2000]. For the calculations it was assumed that the content of metals at the depth of 120-150 cm corresponds to the content of the local geochemical background.

\section{RESULTS AND DISCUSSION}

A varied texture (from medium sand to clay loam) as well as the results of the analyses of basic properties were characteristic for Fluvisols (Table 2,3). The content of clay fraction ranged from 0 to $31 \%$, and at the depth of $120-150 \mathrm{~cm}$ of a few soil profiles sand and sandy loam were found. The reaction was neutral and alkaline and the average content of organic carbon in the plough horizon of arable soils was $12.4 \mathrm{~g} \cdot \mathrm{kg}^{-1}$ and it was twice as low than the one identified in the $0-30 \mathrm{~cm}$ layer of grasslands. In the soils of permanent grasslands the content of organic matter increases naturally. Hoffmann et al. [2009] point to a significant influence of the depositional environment and sedimentary facies on the total organic carbon content (TOC). They showed that TOC increases with increasing clay fraction content. The soil $(0-20 \mathrm{~cm}$ depth) sampled in a frequent flood zone demonstrates a lower content of organic carbon [Gervais-Beaulac et al. 2013]. The loss of biomass (organic matter) during the flood recession results in a net loss of organic carbon to the subsurface soils. Successive flooding triggers Fluvisols impoverishment and changes the pedogenic processes and soil development.

The total content of cadmium, lead, nickel, copper, zinc, manganese and iron in layer $0-30 \mathrm{~cm}$ in the soils ranged from 56.1 to $384 \mathrm{mg} \mathrm{Zn} \cdot \mathrm{kg}^{-1}$, from 9.9 to $41.5 \mathrm{mg} \mathrm{Cu} \cdot \mathrm{kg}^{-1}$, from 418 to 1455 $\mathrm{mg} \mathrm{Mn} \cdot \mathrm{kg}^{-1}$, from 17.2 to $58.8 \mathrm{mg} \mathrm{Pb} \cdot \mathrm{kg}^{-1}$, from 22.2 to $49.9 \mathrm{mg} \mathrm{Ni} \cdot \mathrm{kg}^{-1}$ as well as from 1.22 to $3.23 \mathrm{~g} \mathrm{Fe} \cdot \mathrm{kg}^{-1}$ (Table 4, 5). A significantly higher total content of cadmium, lead, copper and zinc was recorded in the surface layer of grassland soils, as compared with the content of those metals in arable soils (Table 6).

According to the Regulation of Minister of the Environment of September 9, 2002, the total content of $\mathrm{Cd}, \mathrm{Pb}, \mathrm{Ni}, \mathrm{Cu}$ and $\mathrm{Zn}$ found in the 
Table 2. Basic properties of grassland soils

\begin{tabular}{|c|c|c|c|c|c|c|c|c|}
\hline \multirow{3}{*}{$\begin{array}{c}\text { Profile } \\
\text { No. }\end{array}$} & \multirow{3}{*}{ Layer } & \multirow{2}{*}{$\mathrm{pH}$} & \multirow{2}{*}{ Corg } & \multirow{2}{*}{ Sand } & \multirow{2}{*}{ Silt } & \multirow{2}{*}{$\begin{array}{l}\text { Clay } \\
\text { fraction }\end{array}$} & \multicolumn{2}{|c|}{ Texture acc. } \\
\hline & & & & & & & \multirow{2}{*}{$\frac{\text { PTG* }^{*}}{2008}$} & \multirow[t]{2}{*}{ USDA } \\
\hline & & $1 \mathrm{M} \mathrm{KCl}$ & $\mathrm{g} \cdot \mathrm{kg}^{-1}$ & & $\%$ & & & \\
\hline \multirow{3}{*}{1.19} & 1 & 7.03 & 21.1 & 72 & 19 & 9 & gpdr & FSL \\
\hline & 2 & 7.42 & 11.1 & 56 & 29 & 15 & $\mathrm{gl}$ & SL \\
\hline & 3 & 7.48 & 8.7 & 55 & 31 & 14 & gl & SL \\
\hline \multirow{3}{*}{1.24} & 1 & 7.11 & 30.4 & 28 & 48 & 24 & $g z$ & L \\
\hline & 2 & 7.30 & 10.9 & 27 & 52 & 21 & pyi & SiL \\
\hline & 3 & 7.31 & 9.3 & 30 & 51 & 19 & pyi & SiL \\
\hline \multirow{3}{*}{1.26} & 1 & 6.93 & 28.9 & 49 & 35 & 16 & $g z$ & L \\
\hline & 2 & 7.29 & 9.5 & 22 & 59 & 19 & gl & SL \\
\hline & 3 & 7.41 & 5.7 & 32 & 55 & 13 & pyi & SiL \\
\hline \multirow{3}{*}{1.28} & 1 & 6.81 & 39.1 & 39 & 47 & 14 & $g z$ & L \\
\hline & 2 & 7.31 & 6.9 & 35 & 48 & 17 & $g z$ & L \\
\hline & 3 & 6.76 & 4.5 & 22 & 53 & 25 & pyi & SiL \\
\hline \multirow{3}{*}{1.30} & 1 & 6.67 & 34.7 & 20 & 53 & 27 & pyi & SiL \\
\hline & 2 & 7.08 & 6.5 & 38 & 48 & 14 & $g z$ & L \\
\hline & 3 & 7.23 & 1.9 & 70 & 24 & 6 & gpdr & FSL \\
\hline \multirow{3}{*}{1.32} & 1 & 6.68 & 16.2 & 55 & 31 & 14 & gl & $\mathrm{SL}$ \\
\hline & 2 & 7.06 & 16.1 & 20 & 52 & 28 & gi & L \\
\hline & 3 & 7.20 & 9.9 & 17 & 62 & 21 & pyi & SiL \\
\hline
\end{tabular}

Explanation: $1-0-30 \mathrm{~cm}, 2-60-90 \mathrm{~cm}, 3-120-150 \mathrm{~cm}$

* Textural classes are based on the Polish System of Soil Classification [PTG, 2008].

gpdr/FSL - fine sandy loam, gl/SL - sandy loam, gz/L - loam, gi/CL - clay loam, pyi/SiL - silt loam

Table 3. Basic properties of arable soils

\begin{tabular}{|c|c|c|c|c|c|c|c|c|}
\hline \multirow{3}{*}{$\begin{array}{c}\text { Profile } \\
\text { No. }\end{array}$} & \multirow{3}{*}{ Layer } & \multirow{2}{*}{$\begin{array}{l}\mathrm{pH} \\
\mathrm{KCl}\end{array}$} & \multirow{2}{*}{ Corg } & \multirow{2}{*}{ Sand } & \multirow{2}{*}{ Silt } & \multirow{2}{*}{$\begin{array}{l}\text { Clay } \\
\text { fraction }\end{array}$} & \multicolumn{2}{|c|}{ Texture acc. } \\
\hline & & & & & & & \multirow{2}{*}{$\begin{array}{l}\text { PTG } \\
2008\end{array}$} & \multirow[t]{2}{*}{ USDA } \\
\hline & & $1 \mathrm{M} \mathrm{KCl}$ & $\mathrm{g} \cdot \mathrm{kg}^{-1}$ & & $\%$ & & & \\
\hline \multirow{3}{*}{11.20} & 1 & 7.32 & 18.2 & 30 & 56 & 14 & pyi & SiL \\
\hline & 2 & 7.33 & 9.0 & 22 & 58 & 20 & pyi & SiL \\
\hline & 3 & 7.66 & 6.9 & 56 & 36 & 8 & gl & SL \\
\hline \multirow{3}{*}{ II.21 } & 1 & 7.20 & 11.4 & 28 & 52 & 20 & pyi & SiL \\
\hline & 2 & 7.57 & 4.5 & 47 & 40 & 13 & $g z$ & L \\
\hline & 3 & 7.35 & 5.2 & 32 & 52 & 16 & pyi & SiL \\
\hline \multirow{3}{*}{ II. 23} & 1 & 7.40 & 8.4 & 62 & 28 & 10 & gl & SL \\
\hline & 2 & 7.30 & 2.9 & 26 & 57 & 17 & pyi & SiL \\
\hline & 3 & 7.67 & 3.5 & 49 & 45 & 6 & gpdr & FSL \\
\hline \multirow{3}{*}{11.25} & 1 & 7.46 & 8.4 & 39 & 46 & 15 & $g z$ & L \\
\hline & 2 & 7.61 & 6.7 & 39 & 50 & 11 & $g z$ & L \\
\hline & 3 & 7.55 & 0.7 & 95 & 5 & 0 & plśr & MS \\
\hline \multirow{3}{*}{ II.29 } & 1 & 6.79 & 13.7 & 51 & 35 & 14 & $g z$ & L \\
\hline & 2 & 6.64 & 3.7 & 53 & 36 & 11 & gl & SL \\
\hline & 3 & 6.67 & 3.6 & 21 & 50 & 29 & gi & $C L$ \\
\hline \multirow{3}{*}{ II.31 } & 1 & 7.18 & 14.2 & 27 & 42 & 31 & gi & $\mathrm{CL}$ \\
\hline & 2 & 7.43 & 3.8 & 55 & 33 & 12 & $\mathrm{gl}$ & SL \\
\hline & 3 & 7.45 & 1.2 & 85 & 10 & 5 & pgdr & FSL \\
\hline
\end{tabular}

Explanation: see Table 2.

plśr/MS - medium sand, pgdr/LFS - loamy fine sand 
Table 4. Total metal content of grassland soils

\begin{tabular}{|c|c|c|c|c|c|c|c|c|}
\hline \multirow{2}{*}{$\begin{array}{c}\text { Profile } \\
\text { No. }\end{array}$} & \multirow{2}{*}{ Layer } & $\mathrm{Cd}$ & $\mathrm{Pb}$ & $\mathrm{Ni}$ & $\mathrm{Cu}$ & $\mathrm{Zn}$ & $\mathrm{Mn}$ & \multirow{2}{*}{$\frac{\mathrm{Fe}}{\mathrm{g} \cdot \mathrm{kg}^{-1}}$} \\
\hline & & \multicolumn{6}{|c|}{$\mathrm{mg} \cdot \mathrm{kg}^{-1}$} & \\
\hline \multirow{3}{*}{1.19} & 1 & A 1.8 & 22.3 & 18.9 & 10.3 & A159 & 418 & 12.9 \\
\hline & 2 & A 1.4 & 36.5 & 22.9 & 9.6 & 49.0 & 715 & 18.3 \\
\hline & 3 & A 1.2 & 39.3 & 21.2 & 7.2 & 79.9 & 538 & 14.4 \\
\hline \multirow{3}{*}{1.24} & 1 & ${ }^{\mathrm{A}} 2.2$ & 43.8 & A 42.5 & 29.8 & ${ }^{\mathrm{A}} 212$ & 1455 & 32.3 \\
\hline & 2 & A 1.1 & 25.1 & 37.7 & 19.1 & 82.5 & 945 & 27.2 \\
\hline & 3 & 0.9 & 21.8 & 25.4 & 16.5 & 69.5 & 549 & 23.2 \\
\hline \multirow{3}{*}{1.26} & 1 & A1.1 & 36.2 & 27.8 & 22.4 & A155 & 831 & 20.1 \\
\hline & 2 & A1.1 & 25.8 & A 42.8 & 21.6 & 82.0 & 1188 & 30.9 \\
\hline & 3 & 1.0 & 20.7 & 32.1 & 16.9 & 62.7 & 790 & 23.4 \\
\hline \multirow{3}{*}{1.28} & 1 & A2.9 & A58.6 & A 44.1 & A39.8 & AiB 384 & 1177 & 24.6 \\
\hline & 2 & A 1.3 & 24.9 & A35.1 & 18.0 & 70.6 & 756 & 20.9 \\
\hline & 3 & A 1.2 & 21.8 & A43.1 & 16.5 & 80.4 & 1083 & 30.8 \\
\hline \multirow{3}{*}{1.30} & 1 & A3.3 & A58.8 & A49.9 & A41.5 & A238 & 1085 & 26.9 \\
\hline & 2 & A 1.3 & 22.8 & 28.7 & 10.7 & 55.2 & 568 & 15.3 \\
\hline & 3 & A 1.1 & 18.0 & 19.6 & 2.6 & 33.0 & 285 & 7.7 \\
\hline \multirow{3}{*}{1.32} & 1 & A3.1 & A56.0 & A49.9 & A36. 8 & A277 & 1035 & 28.1 \\
\hline & 2 & A 1.7 & 37.4 & A46.7 & 24.6 & A 130 & 1232 & 29.4 \\
\hline & 3 & ${ }^{\mathrm{A}} 2.1$ & 37.3 & A36.9 & 19.4 & A137 & 925 & 21.4 \\
\hline
\end{tabular}

Explanation: $1-0-30 \mathrm{~cm}, 2-60-90 \mathrm{~cm}, 3-120-150 \mathrm{~cm}$

Above the limit for soils: protected by law $-\mathbf{A}$, agricultural land $-\mathbf{B}$

Table 5. Total metal content of arable soils

\begin{tabular}{|c|c|c|c|c|c|c|c|c|}
\hline \multirow{2}{*}{$\begin{array}{l}\text { Profile } \\
\text { No. }\end{array}$} & \multirow{2}{*}{ Layer } & $\mathrm{Cd}$ & $\mathrm{Pb}$ & $\mathrm{Ni}$ & $\mathrm{Cu}$ & $\mathrm{Zn}$ & $\mathrm{Mn}$ & \multirow{2}{*}{$\frac{\mathrm{Fe}}{\mathrm{g} \cdot \mathrm{kg}^{-1}}$} \\
\hline & & \multicolumn{6}{|c|}{$\mathrm{mg} \cdot \mathrm{kg}^{-1}$} & \\
\hline \multirow{3}{*}{ II. 20} & 1 & ${ }^{A} 2.0$ & 39.5 & A36.2 & 19.7 & A156 & 1071 & 26.7 \\
\hline & 2 & A1.1 & 35.9 & A39.2 & 18.5 & 96.4 & 894 & 27.3 \\
\hline & 3 & A1.1 & 24.2 & 16.0 & 8.0 & 42.7 & 424 & 14.0 \\
\hline \multirow{3}{*}{ II. 21} & 1 & 0.6 & 24.3 & 31.0 & 20.1 & 56.1 & 626 & 21.1 \\
\hline & 2 & 0.6 & 17.3 & 24.7 & 10.9 & 47.0 & 474 & 17.7 \\
\hline & 3 & 0.6 & 19.6 & 32.4 & 14.4 & 56.9 & 801 & 23.2 \\
\hline \multirow{3}{*}{ II. 23} & 1 & 0.8 & 17.2 & 22.2 & 9.9 & 68.8 & 432 & 12.2 \\
\hline & 2 & 0.7 & 21.2 & A36.9 & 17.5 & 60.8 & 875 & 25.4 \\
\hline & 3 & 0.5 & 16.7 & 24.6 & 8.7 & 45.4 & 468 & 14.0 \\
\hline \multirow{3}{*}{ II. 25} & 1 & 1.0 & 20.1 & 28.6 & 12.9 & 58.9 & 654 & 19.4 \\
\hline & 2 & 1.0 & 20.2 & 31.9 & 12.5 & 51.4 & 662 & 20.3 \\
\hline & 3 & 0.7 & 9.3 & 7.4 & 1.9 & 6.2 & 122 & 3.4 \\
\hline \multirow{3}{*}{ II.29 } & 1 & A1.4 & 26.8 & 27.6 & 16.0 & 89.1 & 510 & 12.6 \\
\hline & 2 & A1.1 & 18.9 & 25.5 & 6.9 & 47.6 & 332 & 13.1 \\
\hline & 3 & 1.0 & 28.9 & A49.4 & 23.9 & 92.5 & 876 & 30.2 \\
\hline \multirow{3}{*}{ II. 31} & 1 & A 1.8 & 37.7 & A37.1 & 22.1 & A133.5 & 832 & 22.4 \\
\hline & 2 & A1.4 & 20.7 & 25.1 & 10.7 & 42.2 & 417 & 11.1 \\
\hline & 3 & ${ }^{\mathrm{A}} 1.2$ & 15.5 & 14.5 & 1.1 & 22.9 & 231 & 5.0 \\
\hline
\end{tabular}

Explanation: $1-0-30 \mathrm{~cm}, 2-60-90 \mathrm{~cm}, 3-120-150 \mathrm{~cm}$

Above the limit for soils: protected by law $-\mathbf{A}$ 
Table 6. Results of statistical analysis; mean total content of metals (for Anova, the Tukey test)

\begin{tabular}{|c|c|c|c|c|}
\hline \multirow{2}{*}{ Metal } & \multirow{2}{*}{ Layer } & \multirow{2}{*}{$\begin{array}{c}\text { Significant } \\
\text { level }(p)\end{array}$} & $\begin{array}{c}\text { I } \\
\text { grasslands }\end{array}$ & $\begin{array}{c}\text { II } \\
\text { arable soils }\end{array}$ \\
\cline { 4 - 5 } & & \multicolumn{2}{|c|}{ mean content } \\
\hline \multirow{2}{*}{$\mathrm{Cd}$} & 1 & 0.02 & 2.4 & 1.3 \\
& 2 & - & 1.3 & 1.0 \\
\hline \multirow{2}{*}{$\mathrm{Pb}$} & 1 & 0.03 & 45.9 & 27.6 \\
& 2 & - & 28.7 & 22.4 \\
\hline \multirow{2}{*}{$\mathrm{Ni}$} & 1 & - & 38.8 & 30.4 \\
& 2 & - & 35.6 & 30.5 \\
\hline \multirow{2}{*}{$\mathrm{Cu}$} & 1 & 0.03 & 30.1 & 16.8 \\
& 2 & - & 17.3 & 12.8 \\
\hline \multirow{2}{*}{$\mathrm{Zn}$} & 1 & 0.004 & 237 & 93.7 \\
& 2 & - & 78.2 & 57.6 \\
\hline \multirow{2}{*}{$\mathrm{Mn}$} & 1 & - & 1000 & 687 \\
& 2 & - & 901 & 609 \\
\hline \multirow{2}{*}{$\mathrm{Fe}$} & 1 & - & 24.1 & 19.1 \\
& 2 & - & 23.7 & 19.1 \\
\hline
\end{tabular}

Explanation: $1-0-30 \mathrm{~cm}, 2-60-90 \mathrm{~cm}$

$0-30 \mathrm{~cm}$ layer of the soils of the areas protected by law (group A), should not exceed $1.0 \mathrm{mg} \cdot \mathrm{kg}^{-1}$, $50.0 \mathrm{mg} \cdot \mathrm{kg}^{-1}, 35.0 \mathrm{mg} \cdot \mathrm{kg}^{-1}, 30.0 \mathrm{mg} \cdot \mathrm{kg}^{-1}, 100.0$ $\mathrm{mg} \cdot \mathrm{kg}^{-1}$ respectively [Dz. U. No 165 , item 1359]. In all the soil samples of the surface layer of the grasslands as well as three arable soils a higher total content of $\mathrm{Cd}$ than the maximum for the soils of group A was recorded. In the $0-30 \mathrm{~cm}$ layer of grasslands the contents of $\mathrm{Pb}$ and $\mathrm{Cu}$ were higher than the maximum in three samples; $\mathrm{Ni}$ in four samples, and $\mathrm{Zn}$ in all the samples. In the surface layer of arable soils the content of $\mathrm{Cd}$ higher than the maximum was noted in 3 samples and $\mathrm{Ni}_{\mathrm{t}}$ and $\mathrm{Zn}$ - in two samples. Due to the fact that no unfavourable effect of trace elements on the riverside environment was shown as well as that the floodplain areas are under agricultural use, to evaluate the contamination with metals, the references for the soil of agricultural land (group B) were assumed. According to that criterion the soils do not qualify as contaminated with $\mathrm{Cd}, \mathrm{Pb}, \mathrm{Cu}$ and $\mathrm{Zn}$. Only in one of the soil sampling points (I.28) the total content of zinc was higher than the one defined as the maximum for the soils of agricultural land, namely $350 \mathrm{mg} \cdot \mathrm{kg}^{-1}$. The mean total content of $\mathrm{Cd}, \mathrm{Pb}, \mathrm{Ni} \mathrm{Cu}, \mathrm{Zn}, \mathrm{Mn}$, as well as Fe in the Fluvisols studied at the depth of $120-150 \mathrm{~cm}$ was assumed as the content of local geochemical background and it was $1.0 \mathrm{mg} \cdot \mathrm{kg}^{-1}, 22.8 \mathrm{mg} \cdot \mathrm{kg}^{-1}, 26.9$ $\mathrm{mg} \cdot \mathrm{kg}^{-1}, 11,4 \mathrm{mg} \cdot \mathrm{kg}^{-1}, 60.8 \mathrm{mg} \cdot \mathrm{kg}^{-1}, 591 \mathrm{mg} \cdot \mathrm{kg}^{-1}$, and $17.6 \mathrm{~g} \mathrm{~kg}^{-1}$ respectively (Table 7).
Table 7. Basic statistics data of total metal content at the depth of 120-150 cm

\begin{tabular}{|c|c|c|c|c|c|}
\hline \multirow{2}{*}{ Metal } & Min. & Max. & Mean & SD & CV \\
\cline { 2 - 6 } & \multicolumn{5}{|c|}{$\mathrm{mg} \cdot \mathrm{kg}^{-1}$} \\
\hline $\mathrm{Cd}$ & 0.5 & 2.1 & 1.0 & 0.41 & 41.0 \\
\hline $\mathrm{Pb}$ & 9.3 & 39.3 & 22.7 & 8.71 & 38.4 \\
\hline $\mathrm{Ni}$ & 7.4 & 79.4 & 26.9 & 12.33 & 45.8 \\
\hline $\mathrm{Cu}$ & 1.1 & 23.9 & 11.4 & 7.52 & 66.0 \\
\hline $\mathrm{Zn}$ & 6.2 & 137 & 60.7 & 34.91 & 57.5 \\
\hline $\mathrm{Mn}$ & 122 & 1083 & 591 & 302.9 & 51.3 \\
\hline $\mathrm{Fe}$ & 3.4 & 30.8 & 17.6 & 9.24 & 52.5 \\
\hline
\end{tabular}

Explanation: SD - standard deviation, CV - coefficient of variation

Martin and Whitfield [1983] report on the mean total content of metals in soils globally being: $\mathrm{Cd}-0.35 \mathrm{mg} \cdot \mathrm{kg}^{-1}, \mathrm{~Pb}-35 \mathrm{mg} \cdot \mathrm{kg}^{-1}, \mathrm{Ni}-$ $50 \mathrm{mg} \cdot \mathrm{kg}^{-1}, \mathrm{Cu}-30 \mathrm{mg} \cdot \mathrm{kg}^{-1}, \mathrm{Zn}-90 \mathrm{mg} \cdot \mathrm{kg}^{-1}$, $\mathrm{Mn}-1000 \mathrm{mg} \cdot \mathrm{kg}^{-1}$ as well as Fe $40 \mathrm{~g} \cdot \mathrm{kg}^{-1}$. While Kabata-Pendias and Pendias [2001] claim that the mean total content of metals in Fluvisols of Poland is: $\mathrm{Cd}-0.3 \mathrm{mg} \cdot \mathrm{kg}^{-1}, \mathrm{~Pb}-39 \mathrm{mg} \cdot \mathrm{kg}^{-1}, \mathrm{Ni}-9$ $\mathrm{mg} \cdot \mathrm{kg}^{-1}, \mathrm{Cu}-22 \mathrm{mg} \cdot \mathrm{kg}^{-1}, \mathrm{Zn}-84.5 \mathrm{mg} \cdot \mathrm{kg}^{-1}, \mathrm{Mn}$ $-1085 \mathrm{mg} \cdot \mathrm{kg}^{-1}$.

Value $C_{\text {deg }}$ pointing to moderate contamination was recorded in four samples of soil of the surface layer of pastureland, and in study zone no. I.28 a considerable contamination $\left(C_{\text {deg }}>16\right)$ (Table 8 ) was noted, whereas the value of the degree of contamination $C_{d e g}$ demonstrated that in the samples of the $0-30 \mathrm{~cm}$ layer of two research areas of arable soils (II.20, II.31) moderate contamination was identified (Table 9).

The indices $E_{r}^{i}$ and $R I$ suggested by Håkanson [1980] facilitating the evaluation of the potential ecological risk of contamination show a moderate potential ecological risk for $\mathrm{Cd}$ in three samples of the surface layer of arable soils (II.20, II.29) as well as two grasslands (I.19, I.24), while in three others (I.28, I.30, II.31) a considerable potential ecological risk (Table 8,9) was recorded. The value of potential ecological risk index $R I$, associated with the accumulation of a combination of multiple metals, was 150 , which points to a low ecological risk. In three samples taken from the $0-30 \mathrm{~cm}$ layer of grasslands (I.28, I.30, I.32) the value of $R I$ was higher than 120 . The results of $E F$ analysis indicate that the Fluvisols showed low to moderate enrichment with metals. The enrichment factor of respective metals assumed slightly lower values for arable soils, as compared with the soils of grasslands. Values $E F$ calculated 
Table 8. Values of indices for grasslands

\begin{tabular}{|c|c|c|c|c|c|c|c|c|c|c|c|c|c|c|c|c|c|c|}
\hline \multirow{2}{*}{$\begin{array}{c}\text { Profile } \\
\text { No. }\end{array}$} & \multirow{2}{*}{ Layer } & \multicolumn{3}{|c|}{$\mathrm{Cd}_{\mathrm{t}}$} & \multicolumn{3}{|c|}{$\mathrm{Pb}_{\mathrm{t}}$} & \multicolumn{3}{|c|}{$\mathrm{Ni}_{\mathrm{t}}$} & \multicolumn{3}{|c|}{$\mathrm{Cu}_{\mathrm{t}}$} & \multicolumn{3}{|c|}{$Z n_{t}$} & \multirow{2}{*}{$C_{\text {deg }}$} & \multirow{2}{*}{ RI } \\
\hline & & $E F$ & $C_{f}^{i}$ & $E_{r}^{i}$ & $E F$ & $C_{f}^{i}$ & $E_{r}^{i}$ & $E F$ & $C_{f}^{i}$ & $E_{r}^{i}$ & $E F$ & $C_{f}^{i}$ & $E_{r}^{i}$ & $E F$ & $C_{f}^{i}$ & $E_{r}^{i}$ & & \\
\hline \multirow{2}{*}{ I.19 } & 1 & 2.4 & 1.8 & 54 & 1.3 & 1.0 & 5.0 & 1.0 & 0.7 & 3.5 & 1.2 & 0.9 & 1.8 & 3.6 & 2.6 & 2.6 & 7.0 & 66.9 \\
\hline & 2 & 1.3 & 1.4 & 42 & 1.5 & 1.6 & 8.0 & 0.8 & 0.8 & 4.0 & 0.8 & 0.8 & 1.6 & 0.8 & 0.8 & 0.8 & 5.4 & 56.4 \\
\hline \multirow{2}{*}{1.24} & 1 & 1.2 & 2.2 & 66 & 1.0 & 1.9 & 9.5 & 0.9 & 1.6 & 8.0 & 1.4 & 2.6 & 5.2 & 1.9 & 3.5 & 3.5 & 11.8 & 92.2 \\
\hline & 2 & 0.7 & 1.1 & 33 & 0.7 & 1.1 & 5.5 & 0.9 & 1.4 & 7.0 & 1.1 & 1.7 & 3.4 & 0.9 & 1.4 & 1.4 & 6.7 & 50.3 \\
\hline \multirow{2}{*}{1.26} & 1 & 1.0 & 1.1 & 33 & 1.4 & 1.6 & 8.0 & 0.9 & 1.0 & 5.0 & 1.7 & 2.0 & 4.0 & 2.2 & 2.5 & 2.5 & 8.2 & 52.5 \\
\hline & 2 & 0.6 & 1.1 & 33 & 0.6 & 1.1 & 5.5 & 0.9 & 1.6 & 8.0 & 1.1 & 1.9 & 3.8 & 0.8 & 1.3 & 1.3 & 7.0 & 51.6 \\
\hline \multirow{2}{*}{1.28} & 1 & 2.1 & 2.9 & 87 & 1.8 & 2.6 & 13.0 & 1.2 & 1.6 & 8.0 & 2.5 & 3.5 & 7.0 & 4.5 & 6.3 & 6.3 & 16.9 & 121.3 \\
\hline & 2 & 1.1 & 1.3 & 39 & 0.9 & 1.1 & 5.5 & 1.1 & 1.3 & 6.5 & 1.3 & 1.6 & 3.2 & 1.0 & 1.2 & 1.2 & 6.5 & 55.4 \\
\hline \multirow{2}{*}{1.30} & 1 & 2.1 & 3.3 & 99 & 1.7 & 2.6 & 13.0 & 1.2 & 1.9 & 9.5 & 2.4 & 3.6 & 7.2 & 2.6 & 3.9 & 3.9 & 15.3 & 132.6 \\
\hline & 2 & 1.5 & 1.3 & 39 & 1.2 & 1.0 & 5.0 & 1.2 & 1.1 & 5.5 & 1.1 & 0.9 & 1.8 & 1.0 & 0.9 & 0.9 & 5.2 & 52.2 \\
\hline \multirow{2}{*}{1.32} & 1 & 1.9 & 3.1 & 93 & 1.5 & 2.5 & 12.5 & 1.2 & 1.9 & 9.5 & 2.0 & 3.2 & 6.4 & 2.9 & 4.6 & 4.6 & 15.3 & 126.0 \\
\hline & 2 & 1.0 & 1.7 & 51 & 1.0 & 1.6 & 8.0 & 1.0 & 1.7 & 8.5 & 1.3 & 2.2 & 4.4 & 1.3 & 2.1 & 2.1 & 9.3 & 74.0 \\
\hline
\end{tabular}

Explanation: $1-0-30 \mathrm{~cm}, 2-60-90 \mathrm{~cm}$; EF - enrichment factor, Cfi - contamination factor,

Eir - potential ecological risk, Cdeg - contamination degree, RI - potential ecological risk index

Table 9. Values of indices for arable soils

\begin{tabular}{|c|c|c|c|c|c|c|c|c|c|c|c|c|c|c|c|c|c|c|}
\hline \multirow{2}{*}{$\begin{array}{c}\text { Profile } \\
\text { No. }\end{array}$} & \multirow{2}{*}{ Layer } & \multicolumn{3}{|c|}{$\mathrm{Cd}_{\mathrm{t}}$} & \multicolumn{3}{|c|}{$\mathrm{Pb}_{\mathrm{t}}$} & \multicolumn{3}{|c|}{$\mathrm{Ni}_{\mathrm{t}}$} & \multicolumn{3}{|c|}{$\mathrm{Cu}_{\mathrm{t}}$} & \multicolumn{3}{|c|}{$\mathrm{Zn}_{\mathrm{t}}$} & \multirow{2}{*}{$\mathrm{C}_{\mathrm{deg}}$} & \multirow{2}{*}{ RI } \\
\hline & & $E F$ & $C_{f}$ & $E r$ & $E F$ & $C_{f}$ & $E r$ & $E F$ & $C_{f}$ & Er & $E F$ & $C_{f}$ & Er & $E F$ & $C_{f}$ & $E r$ & & \\
\hline \multirow{2}{*}{ II. 20} & 1 & 1.3 & 2.0 & 60 & 1.1 & 1.7 & 8.5 & 0.9 & 1.3 & 6.5 & 1.1 & 1.7 & 3.4 & 1.7 & 2.6 & 2.6 & 9.3 & 81.5 \\
\hline & 2 & 0.7 & 1.1 & 33 & 1.0 & 1.6 & 8 & 0.9 & 1.5 & 7.5 & 1.0 & 1.6 & 3.2 & 1.0 & 1.6 & 1.6 & 7.4 & 52.8 \\
\hline \multirow{2}{*}{ II.21 } & 1 & 0.5 & 0.6 & 18 & 0.9 & 1.1 & 5.5 & 1.0 & 1.1 & 5.5 & 1.5 & 1.8 & 3.6 & 0.8 & 0.9 & 0.9 & 5.5 & 33.5 \\
\hline & 2 & 0.6 & 0.6 & 18 & 0.8 & 0.8 & 4.0 & 0.9 & 0.9 & 4.5 & 0.9 & 1.0 & 2.0 & 0.8 & 0.8 & 0.8 & 4.1 & 29.3 \\
\hline \multirow{2}{*}{ II.23 } & 1 & 1.1 & 0.8 & 24 & 1.1 & 0.8 & 4.0 & 1.2 & 0.8 & 4.0 & 1.2 & 0.9 & 1.8 & 1.6 & 1.1 & 1.1 & 4.4 & 34.9 \\
\hline & 3 & 0.5 & 0.7 & 21 & 0.6 & 1.0 & 5.0 & 0.9 & 1.4 & 7.0 & 1.1 & 1.5 & 3.0 & 0.7 & 1.0 & 1.0 & 5.6 & 36.5 \\
\hline \multirow{2}{*}{ II. 25} & 1 & 0.9 & 1.0 & 30 & 0.8 & 0.9 & 4.5 & 1.0 & 1.0 & 5.0 & 1.0 & 1.1 & 2.2 & 0.9 & 1.0 & 1.0 & 5.0 & 42.7 \\
\hline & 3 & 0.9 & 1.0 & 30 & 0.8 & 0.9 & 4.5 & 1.0 & 1.2 & 6.0 & 0.9 & 1.1 & 2.2 & 0.7 & 0.8 & 0.8 & 5.0 & 43.0 \\
\hline \multirow{2}{*}{ II.29 } & 1 & 1.9 & 1.4 & 42 & 1.6 & 1.2 & 6.0 & 1.4 & 1.0 & 5.0 & 1.9 & 1.4 & 2.8 & 2.0 & 1.5 & 1.5 & 6.5 & 57.3 \\
\hline & 2 & 1.5 & 1.1 & 33 & 1.1 & 0.9 & 4.5 & 1.3 & 0.9 & 4.5 & 0.8 & 0.6 & 1.2 & 1.0 & 0.8 & 0.8 & 4.3 & 44.0 \\
\hline \multirow{2}{*}{ II.31 } & 1 & 1.4 & 1.8 & 54 & 1.3 & 1.6 & 8.0 & 1.1 & 1.4 & 7.0 & 1.5 & 1.9 & 3.8 & 1.7 & 2.2 & 2.2 & 8.9 & 75.0 \\
\hline & 2 & 2.2 & 1.4 & 42 & 1.4 & 0.9 & 4.5 & 1.5 & 0.9 & 4.5 & 1.5 & 0.9 & 1.8 & 1.1 & 0.7 & 0.7 & 4.8 & 53.5 \\
\hline
\end{tabular}

Explanation: see Table 8 .

for $\mathrm{Cd}, \mathrm{Zn}, \mathrm{Cu}$ and $\mathrm{Pb}$ in most cases indicate the anthropogenic origin of those heavy metals.

The values of contamination factor revealed higher levels of accumulation of heavy metals in grassland soils, which shows that the method of their use has a significant effect on the total content of metals. Józefowska et al. [2014] report, based on their research, on different types of land use not affecting the content of heavy metals and only the accumulation index of lead was higher in grassland soils than in arable land soils.

In statistics, Ward's method is a criterion applied in hierarchical cluster analysis. Figure 1 is the result of the cluster analysis and two main groups have been distinguished in the dendrogram (Figure 1).

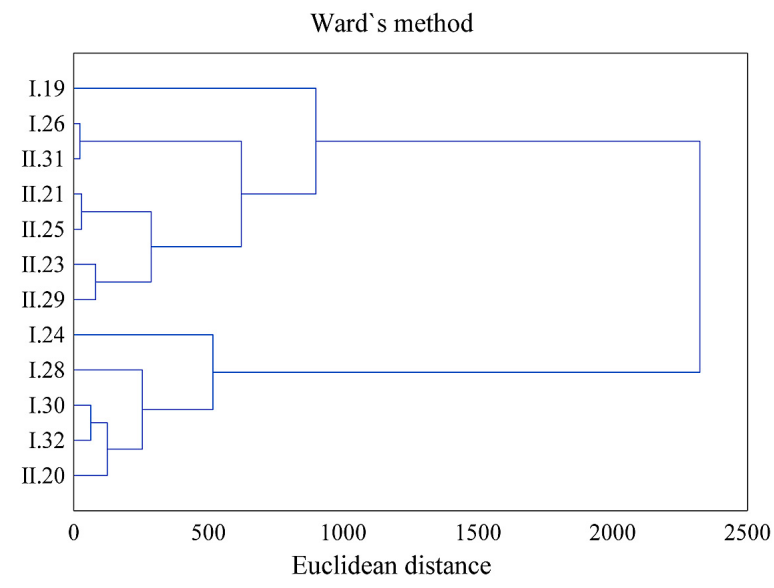

Figure 1. Cluster analysis of $\mathrm{Cd}_{\mathrm{t}}, \mathrm{Pb}_{\mathrm{t}}, \mathrm{Ni}_{\mathrm{t}}, \mathrm{Cu}_{\mathrm{t}}, \mathrm{Zn}_{\mathrm{t}}$, $\mathrm{Fe}_{t}, \mathrm{Mn}_{\mathrm{t}}$ in the surface horizon of Fluvisols 
The results of the analysis show that the method used determines the content of heavy metals in the surface layer of the Fluvisols under study. A similar total content of metals was reported for the samples ( 1 cluster) taken from 5 arable soils and 2 pastures (II.23, II.29, II.21, II.25, II.31 and I.26, I.19) as well as samples (2 cluster) taken from 4 pastures and one arable soil (I.24, I.28, I.30, I.32 and II.20). In the Fluvisols investigated a significantly positive correlation between the content of $\mathrm{C}$ org and the total content of metals was found. The soil samples with a higher content of the clay fraction also contained a significantly higher total content of $\mathrm{Pb}, \mathrm{Ni}, \mathrm{Cu}, \mathrm{Zn}, \mathrm{Mn}$ and $\mathrm{Fe}$ (Table 10). Between the total content of $\mathrm{Cd}, \mathrm{Pb}$, $\mathrm{Cu}$ and $\mathrm{Zn}$ and the content of Corg higher values of the coefficient of correlation than with the clay fraction were noted, unlike Ni, Mn and Fe. A significantly positive correlation between the content of organic carbon and the content of metals confirms a significant role of humus in bonding metals [Van Gestel 2008]. Numerous interactions were identified between the total content of respective metals and some of them are very high dependencies with the value of the coefficient of correlation of $r>0.90(p<0,05)$.

Table 10. Significant correlation coefficient at $p<0.05$

\begin{tabular}{|c|c|c|c|c|c|c|c|}
\hline Soil properties & $\mathrm{Cd}_{\mathrm{t}}$ & $\mathrm{Pb}_{\mathrm{t}}$ & $\mathrm{Ni}_{\mathrm{t}}$ & $\mathrm{Cu}_{\mathrm{t}}$ & $\mathrm{Zn}_{\mathrm{t}}$ & $\mathrm{Mn}_{\mathrm{t}}$ & $\mathrm{Fe}_{\mathrm{t}}$ \\
\hline $\mathrm{C}$ org & 0.75 & 0.81 & 0.45 & 0.77 & 0.88 & 0.59 & 0.40 \\
\hline Clay fraction & & 0.49 & 0.80 & 0.65 & 0.35 & 0.74 & 0.80 \\
\hline $\mathrm{Cd}_{\mathrm{t}}$ & & 0.87 & 0.54 & 0.73 & 0.87 & 0.54 & 0.34 \\
\hline $\mathrm{Pb}_{\mathrm{t}}$ & & & 0.66 & 0.84 & 0.88 & 0.69 & 0.54 \\
\hline $\mathrm{Ni}_{\mathrm{t}}$ & & & & 0.87 & 0.63 & 0.89 & 0.90 \\
\hline $\mathrm{Cu}_{\mathrm{t}}$ & & & & & 0.86 & 0.83 & 0.77 \\
\hline $\mathrm{Zn}_{\mathrm{t}}$ & & & & & & 0.65 & 0.49 \\
\hline $\mathrm{Mn}_{\mathrm{t}}$ & & & & & & & 0.93 \\
\hline $\mathrm{Fe}_{\mathrm{t}}$ & & & & & & & \\
\hline
\end{tabular}

Apart from chemical and metallurgical industries, municipal waste is responsible for most significant river contaminations which result in soil degradation in their close vicinity, both locally and regionally. In the Fluvisols of the Vistula floodplain areas the content of heavy metals is usually elevated, as compared with the content of the geochemical background and fluvial deposits can contain more mobile forms of metals [Czarnowska et al. 1995, Dąbkowska-Naskręt et al. 2000, Kobierski, Piotrowska 2010]. Skorbiłowicz and Samborska [2014] demonstrate that the arable land in the Vistula river catchment are characterized by a low content of $\mathrm{Cu}$, whose average value was $8.2 \pm 1.5 \mathrm{mg} \cdot \mathrm{kg}^{-1}$, while the average nickel content was $10.6 \pm 5.1 \mathrm{mg} \cdot \mathrm{kg}^{-1}$. An excessive content of heavy metals, both indispensable to plants and not playing metabolic functions, can have an unfavourable effect on plants due to the capacity of metals for bio-accumulation. As a result of the alkalization of the soil environment and the higher the content of humus substances and the clay fraction in soil, the bioavailability of metals can get limited [Kabata-Pendias, Pendias 2001].

\section{CONCLUSIONS}

1. The total content of metals in Fluvisols depends on the use of soils. A higher total content of metal was found in the soils of grasslands.

2. Compliant with Regulation of Minister of the Environment of September 9, 2002, the total content of cadmium and zinc found in the $0-30 \mathrm{~cm}$ layer of all the pastureland investigated was higher from the maximum for the areas protected by law (land group A). $\mathrm{A}$ higher total content of $\mathrm{Pb}$ and $\mathrm{Ni}$ than the maximum for the soils of the protected areas was reported also in a few soil samples in the surface horizon of Fluvisols. No unambiguous, unfavourable, effect of trace elements was found in the riverside environment and so to evaluate the contamination the limit values specified in Regulation for agricultural land were assumed. According to this criterion the Fluvisols of the Grudziądz Basin, besides one soil sampling point, do not qualify as contaminated with the metals under the study.

3. The values of enrichment factor calculated for $\mathrm{Cd}, \mathrm{Pb}, \mathrm{Ni}, \mathrm{Cu}$ and $\mathrm{Zn}$ were slightly higher for the soils of grasslands and point to the anthropogenic accumulation of metals, which concerns especially zinc for which in the surface horizon of grasslands the value of EF ranges from 1.9 to 4.5 .

4. Potential ecological risk demonstrated that overall risk caused by the content of metals ranges from low to considerable. The value of potential ecological risk index was found to be low, and varied between 29.3 to 132.6 indicating that the Fluvisols were not contaminated with heavy metals. 


\section{Acknowledgements}

The studies were financed by the NCN (National Science Centre), Poland, under research project No. 2716/B/P01/2011/40.

\section{REFERENCES}

1. Crock J.G., Severson R. 1980. Four reference soil and rock samples for measuring element availability in the western energy regions. U.S. Geological Survey circular 841, 16.

2. Czarnowska K., Broda D., Chojnicki J., Turemka E. 1995. Heavy metals in illuvial soils of the Vistula valley. Roczn. Glebozn. 46, 3/4, 5-18 [in Polish].

3. Dąbkowska-Naskręt H., Kobierski M., Różański S. 2000. Trace elements distribution and mobility in alluwial soils of the Wisła River Valley, Poland. Mengen und Spurenelemente, 20. Arbeitstagung. Jena, 152-157.

4. Dziennik Ustaw 2002. Rozporządzenie Ministra Środowiska w sprawie standardów jakości gleby oraz jakości ziemi. Nr 165, poz. 1359. [in Polish]

5. Gervais-Beaulac V., Saint-Laurent D., Berthelot J.S., Mesfioui M. 2013. Organic carbon distribution in alluvial soils according to different flood risk zones. J. Soil Sci. Environ. Manage., 4, 8, 169-177.

6. Håkanson L. 1980. An ecological risk index for aquatic pollution control - a sedimentological approach. Water Research 14, 975-1101.

7. Harmsen J. 2007. Measuring bioavailability: from a scientific approach to standard methods. J. Environ. Qual., 36, 5, 1420-1428.

8. Hoffmann T, Glatzel S, Dikau R. 2009. A carbon storage perspective on alluvial sediment storage in the Rhine catchment. Geomorphology 108, 127-137.

9. ISO 10390: 2005. Soil quality - Determination of $\mathrm{pH}$.

10. Józefowska A., Miechówka A., Gąsiorek M., Zadrożny P. 2014. Content of zinc, lead and cadmium in selected agricultural soils in the area of the Śląskie and Ciężkowickie foothills. J. Ecol. Eng., 15, 1, 74-80.

11. Kabata-Pendias A. 2004. Soil-plant transfer of trace elements - an environmental issue. Geoderma 122. 143-149.

12. Kabata-Pendias A., Pendias H. 2001. Trace elements in soils and plants. Boca Raton. London.
New York. Washington DC, 1-331.

13. Kobierski M., Piotrowska A. 2010. Profile distribution of heavy metals and enzymatic activity in Fluvisols of the Vistula River Valley, Poland. Fressenius Environ. Bulletin 19, No 2b, 303-311.

14. Kordowski J. 2003. Internal structures and granulometry of lower Vistula valley overbank deposits in the Toruń and Unisław Basins. Przegląd Geograficzny 75, 4, 601-621.

15. Macklin M.G., Klimek K. 1992. Dispersal, storage and transformation of metal contaminated alluvium in the Upper Vistula basin, southwest Poland. Appl. Geogr., 12, 7-30.

16. Martin J.-M., Meybeck M. 1979. Elemental massbalance of material carried by major world rivers. Marine Chemistry 7, 3, 173-206.

17. Martin J.-M., Whitfield M. 1983. The significance of the river input of chemical elements to the ocean. [In:] Trace metals in seawater. Wong C.S., Boyle E., Bruland K.W., Goldberg E.D. (Editors), Plenum, New York. 265-296.

18. PN-ISO-11277: 2005. Soil quality - Determination of particle size distribution in mineral soil material - Method by sieving and sedimentation.

19. Saint-Laurent D., St-Laurent J., Lavoie L., Drouin A., Ghaleb B. 2010. Floodplain sedimentation rates, soil properties and recent flood history in Southern Québec. Global. Planetary Change 70, 76-91.

20. Singh K., Malik A., Sinha S., Singh V., Murthy R. 2005. Estimation of source of heavy metal contamination in sediments of Gomti river (India) using principal component analysis. Water Air Soil Pollut., 166, 321-341.

21. Skorbiłowicz E., Samborska A. 2014. Content of copper and nickel in soils of Vistula River catchment. J. Ecol. Eng., 15, 2, 53-59.

22. Sutherland R.A., Tolosa C.A, Tack F.M.G., Verloo M.G. 2000. Characterization of selected element concentration and enrichment ratios in background and anthropogenically impacted roadside areas. Arch. Environ. Contam. Toxicol., 38, 428-438.

23. Van Gestel C.A.M. 2008. Physico-chemical and biological parameters determine metal bioavailability in soils. Sci. Total Environ., 406, 385-395.

24. Wyżga B., Ciszewski D. 2010. Hydraulic controls on the entrapment of heavy metal-polluted sediments on a floodplain of variable width, the upper Vistula River, southern Poland. Geomorphology 117, 272-286. 